\title{
Preparation, Structural Study, Theoretical Treatment and Biological Activity of Cr (III), Ni (II), Cd (II) and V (IV) Complexes of Tetradentate Ligand Bis [4-Phenyl-3 (2- Propenyl) Thio-1, 2, 4-Triazole-5yl] Methane
}

\author{
Mahasin F. Alias, Manal O. Hamza and Tamara A. Kareem \\ Department of Chemistry, College of Science for Women, University of Baghdad, Baghdad-Iraq.
}

\begin{abstract}
Some transition metal complexes Cr (III), Ni (II), Cd (II) and V (IV) Complexes of olefinic bistriazole as a ligand have been synthesized and characterized. The prepared complexes were identified and their structural geometries were suggested by using Flame Atomic Absorption technique, FT-IR and Uv-Visible Spectrophotometer as well as to Magnetic Susceptibility and Conductivity measurement. Semi-empirical methods (PM3 and MINDO/3) were carried out to evaluate the vibration frequencies, heat of formation $\left(\Delta \mathrm{H}^{\circ} f\right)$ and binding energy $\left(\Delta \mathrm{E}_{\mathrm{b}}\right)$ for all metal complexes. And it is also studying their biological activity against two selected microorganisms (pseudomonas aeruginosa and staphylococcus aureus).
\end{abstract}

\section{Introduction}

Heterocyclic molecules (thiotriazol) containing olefinic group are considered to be good coordinative compounds because they contain the hard nitrogen as well as soft sulfur atoms in addition to presence of unsaturated group in these molecules. This make it capable to form organometallic compounds, and because of their established biological activity with structural features and behavior [1-4]. Transition metal alkenes complexes play a critical role in a variety of important organometallic reactions such as olefin polymerization, hydrofomylation [5]; catalytical aspects $[4,6]$ and it can be postulated that chemotheraptic area is the main and widely vast field in triazole applications.

In this paper some transition metal complexes of olefinic bistriazole as a ligand have been synthesized and characterized. Additional understandings of the complexes have been gained by theoretical treatment study. It is also studying their biological activity against two selected microorganisms.

\section{Experimental}

b) Materials, physical measurement and analysis:

The chemicals were of highest purity and used as received. Melting points were recorded on Gallenkamp melting point apparatus. Electronic spectra were obtained using shimadza uv-visible spectrophotometer at room temperature. FT-IR spectra were recorded using shimadza-8000 spectrophotometer for the range of (4000-200) $\mathrm{cm}^{-1}$ and samples were measured as CsI disc. The metal content was estimated using atomic absorption shimadza AA670 spectrophotometer. Conductivity measurement were obtained using WTW conductmeter in DMF solvent using $\left(10^{-3} \mathrm{M}\right)$ at $25^{\circ} \mathrm{C}$, Magnetic susceptibility measurements were obtained at $25^{\circ} \mathrm{C}$ on the solid state applying Faradays method using Bruker BM6 instrument.

\section{c) Preparation the ligand and its metal complexes:}

\section{1- Preparation of the ligand:}

The method used to prepare the bis [4phenyl-3(2- propenyl) thio-1, 2, 4-triazole-5yl] methane (OBTM) as reported in literature [7]. It is starting from ethylmalonate and hydrazine according to the following scheme: 


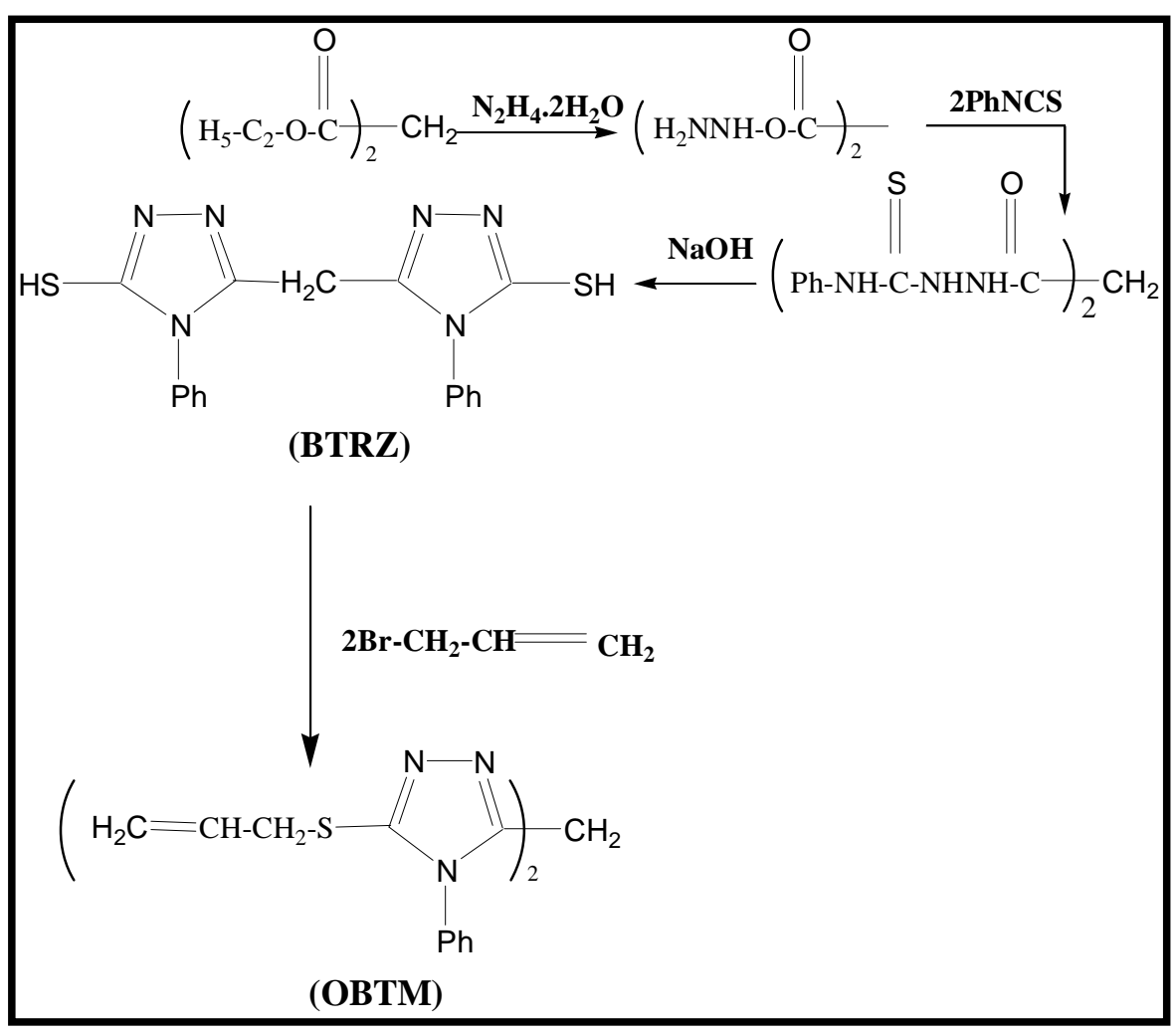

The physical properties of the product are shown in Table (1), which is characterized by physical method and spectroscopy.

\section{2- Preparation of Complexes:}

An appropriate amount of nickel nitrate monohydrate, chromium chloride trihydrate, cadmium chloride and vanadium sulphate were dissolved each one in (5) $\mathrm{ml}$ absolute ethanol and was added to a solution comprise of (OBTM) ligand in (2:1) mole ratio. The mixture was refluxed for 2 hours and then concentrated until precipitate was obtained. The colored precipitates were filtered and recrystallized from dichloromethane. The physical data of the prepared complexes are shown in Table (1).

\section{c) Theoretical Calculation}

HyperChem-6 program [8] is a sophisticated molecular modeler, editor and powerful computational package that are known for its quality, flexibility and easy of use, uniting 3D visualization and animation with quantum chemical calculations, mechanic and dynamic. HyperChem-6 can plot orbital functions resulting from semi-empirical quantum mechanical calculation, as well as the electrostatic potential. The total charge density or the total spin density can also be determined during a semi-empirical calculation. This information is useful in determining reactivity and correlating calculation results with experimental data. HyperChem offers ten semi-empirical molecular orbital methods, with options for organic and main group compounds, for transition metal complexes and spectral simulation [9]. PM3 level of semiempirical method was used for calculation the heat of formation $\left(\Delta \mathrm{H}^{\mathrm{o}} f\right)$ and binding energy $\left(\Delta \mathrm{E}_{\mathrm{b}}\right)$ for all metal complexes.

\section{d) Bactericidal activity}

The bactericidal activity of OBTM and its metal complexes was evaluated against representative gram-positive and gram negative bacteria by agar plate method [10]. All drugs were prepared freshly by dissolving in DMF to obtain a final concentration (10) and (5) $\mathrm{mM}$. All bacteria were cultivated in nutrient agar. The results are found in Table (4).

\section{Results and Discussion}

\section{1) Chemistry}

Stable complexes were isolated in all cases based on the metal analysis data, the general formula of the complexes can be depicted as $\left[\mathrm{M}(\mathrm{OBTM})\left(\mathrm{H}_{2} \mathrm{O}\right)_{4}(\mathrm{X})_{4}\right] \mathrm{CL}_{\mathrm{n}}$. $\mathrm{S}=\mathrm{EtOH}$, where $\mathrm{M}=\mathrm{Ni}$ and $\mathrm{Cr}, \mathrm{X}=\mathrm{NO}_{3}$ and $\mathrm{Cl}, \mathrm{n}=0,2$ and $\mathrm{S}=4,2$ respectively and $[\mathrm{M}(\mathrm{OBTM})(\mathrm{X}) \mathrm{n}] \mathrm{S}$, where $\mathrm{M}=\mathrm{V}$ and $\mathrm{Cd}$, $\mathrm{X}=2 \mathrm{SO}_{4}$ and $4 \mathrm{Cl}, \mathrm{S}=\mathrm{EtOH}$ and $\mathrm{H}_{2} \mathrm{O}$ respectively. 
OBTM is a potential ligand capable to form organometallic compounds [4,7]. So it expected that FT-IR measurements are highly informative with respect to the complexation behavior with various metal ions. The characteristic frequencies of the free ligand and its complexes were readily assigned based on comparison with literature references $[4,11,12]$. The FT-IR spectra data of all complexes are listed in - characterized. In addition, the shift in its position gives good indication about the type of bonding with the metal as through sigma or pi- bonding.

The spectrum of OBTM is characterized by the presence of an essential band which belong to olefin group at (1631) $\mathrm{cm}^{-1}$ and other at (949.6 and 860.2) $\mathrm{cm}^{-1}$ which originate from the out of the plane bending vibration of the vinylic group. All the prepared complexes spectra show red shift of the olefinic band absorption by $(\approx 90) \mathrm{cm}^{-1}$ and by $(\approx 35.4) \mathrm{cm}^{-1}$ for the vinylic group, this indicating that the coordinate of this ligand through $\pi$-bonding [11]. This was further indicated by the appearance of $\mathrm{M}-\mathrm{C}$ band absorption. The spectra also display $v_{\mathrm{C}-\mathrm{S}}$ band shifted by $(\approx 10) \mathrm{cm}^{-1}$ indicating the participation of sulfur atom coordinate [12,13]. Therefore the ligand may be considered to behave as a tetradentate through two sulfur atoms and two olefinic groups, to form an octahedral for the dimeric chromium and nickel complexes and tetrahedral for the dimeric cadmium complex, in addition to square pyramide for the dimeric vanadium complex. There is also appearance of nitrate bands group [11] showing the linkage of this group through one oxygen atom for the nickel complex and (M-Cl) band stretching frequencies for the chromium and cadmium complexes, as well as a strong band was observed at $(995) \mathrm{cm}^{-1}$ due to $(\mathrm{V}=\mathrm{O})$ stretching mode in vanadium complex $[11,12]$. While band related to sulfate anion in the same complex was observed at (1505) $\mathrm{cm}^{-1}$ indicated a bidentate behavior. A broad band was observed around (3430-3510) $\mathrm{cm}^{-1}$ in the spectra of all prepared compounds, assigned as $\left(v_{\mathrm{OH}}\right)$ suggested the presence of water or ethanol molecule, while a week band observed at $(1608) \mathrm{cm}^{-1}$ in the spectra of nickel and chromium complexes suggests the presence of coordinative water [11].

The electronic spectra of the olive green of vanadyl (IV) complex show two main absorption bands, Table (3), which are assigned to the transition ${ }^{2} \mathrm{~B}_{2} \rightarrow{ }^{2} \mathrm{E}$ and ${ }^{2} \mathrm{~B}_{2} \rightarrow{ }^{2} \mathrm{~B}_{1}$ respectively in a square pyramidal geometry [14,15]. The magnetic moment (2.1 B.M) is higher than spin value of the vanadium metal only; this is because of a higher orbital contribution [16, 17]. Conductivity measurement in DMF showed that the complex was no electrolyte. Two bands were observed within the range measurement for the green chromium complex. They have maxima at about (16.590 and 25.936) $\mathrm{cm}^{-1}$. These are spin-allowed and laborite forbidden $\mathrm{d}-\mathrm{d}$ transition. The third band $v_{3}$ was calculated reference to T.S. diagram for $\mathrm{d}^{3}$ configuration, Table (3). The magnetic value (3.2 B.M) was observed and this value agreement with octahedral geometry around Cr (II) ion [12,14,16]. Conductance measurement indicated that the complex was ionic behavior.

Square planer nickel (II) complexes are commonly orange or red, but green examples are also known [14, 16]. Table (3) provides further evidence in favor of distorted octahedral structure. The ligand crystal field $10 \mathrm{Dq}$ is equal to $v_{1}$, which is characteristic of octahedral geometry. Three transitions bands are shown in the spectrum of nickel complex and their assigned can be shown in Table (3). The magnetic susceptibilities measurements show the nickel ion in its greenish complex to be paramagnetic with (3.11 B.M). Conductivity measurements in DMF solvent show the complex to be non ionic.

\section{2) Biological Activity:}

The results obtained for biological activity for the olefinic compound and its complexes are given in Table (4). Diameter of inhibition zone $(\mathrm{mm})$ including the disc diameter was measured for each treatment. The ligand showed no antimicrobial activity against pseudomonas aeruginosa and slightly active toward staphylococcus aureus. The chromium and vanadium complexes exhibited the maximum antimicrobial activity against all organisms used in this study. Moreover, cadmium complex showed moderate 
antimicrobial activity against gram positive and gram negative organisms and nickel complex produced (+ve) antimicrobial activity on positive organism and (-ve) activity on the other.

3) Theoretical Study of Ligand and Its Metal Complexes in Gas Phase.

i. The program: HyperChem-6 was used for the semi-empirical calculations, at optimized geometries energies, the result on PM3 method of calculation in gas phase for the heat of formation $\left(\Delta \mathrm{H}^{\mathrm{o}} f\right)$ and binding energy $\left(\Delta E_{b}\right)$ for the ligand and their complexes were calculated and tabulated in Table (5). PM3 and MINDO/3. Semi-empirical methods were used to evaluate the vibrational spectra of the BTRZ and the ligand OBTM to compare the theoretically calculated wave numbers with the experimental values. Theoretical calculated wave numbers for the ligand showed that some deviations were generally acceptable in theoretical calculations and were described in
Tables (2) and (5), and showed in the Figs. (2) and (3). Also HOMO and LOMO energies for BTRZ and the ligand were calculated using PM3 semi-empirical method, the HOMO and LOMO values were plotted as $2 \mathrm{D}$ contour to get more information about these molecules. The results of calculation showed that the LOMO of transition metal ion prefer to react with the HOMO of sulfer and nitrogen atoms of Schiff base ligand.

ii. Optimized Geometries Energy of Metal Complexes for Olefinic Compound:

All theoretically probable structures of metal complexes with the ligand have been calculated to search for the most probable model building stable structure. These shapes [Fig. (4)] showed the calculated optimal geometries for ligand and its metal complexes. The results of PM3 semiempirical method of calculation in gas phase for the binding energy and heat of formation of $\mathrm{Ni}$ (II), Cd (II) and $\mathrm{Cr}$ (III) can be found in Table (5).

Table (1)

Physical data for the ligand and its metal complexes.

\begin{tabular}{|c|c|c|c|c|c|c|}
\hline \multirow{2}{*}{ Cop. } & \multirow{2}{*}{ Color } & \multirow{2}{*}{$\begin{array}{l}\text { Melting } \\
\text { Point }{ }^{\circ} \mathrm{C}\end{array}$} & \multirow{2}{*}{$\begin{array}{c}\text { Yield } \\
\%\end{array}$} & \multicolumn{2}{|c|}{ Metal conten \% } & \multirow{2}{*}{ Suggested formula } \\
\hline & & & & Calc. & Found & \\
\hline OBTM & White & $118-120$ & 92 & - & - & $\mathrm{C}_{23} \mathrm{H}_{22} \mathrm{~N}_{6} \mathrm{~S}_{2}$ \\
\hline VL & $\begin{array}{l}\text { Olive } \\
\text { green }\end{array}$ & 184-186 & 40 & 17.33 & 20.43 & $\begin{array}{c}{\left[(\mathrm{VO})_{2 \mathrm{~L}}\left(\mathrm{SO}_{4}\right)_{2}\right] .} \\
\text { EtOH }\end{array}$ \\
\hline $\mathrm{CrL}$ & $\begin{array}{l}\text { Dark } \\
\text { green }\end{array}$ & $158-160$ & 86 & 11.21 & 10.7 & {$\left[\mathrm{Cr}_{2} \mathrm{~L}\left(\mathrm{H}_{2} \mathrm{O}\right)_{4} \mathrm{Cl}_{4}\right] \cdot \mathrm{Cl}_{2}$} \\
\hline NiL & $\begin{array}{l}\text { Greenish } \\
\text { grey }\end{array}$ & $60-62$ & 92 & 10.98 & 10.42 & $\begin{array}{c}{\left[\mathrm{Ni}_{2} \mathrm{~L}\left(\mathrm{H}_{2} \mathrm{O}\right)\left(\mathrm{NO}_{3}\right)_{4}\right]} \\
4 \mathrm{EtOH}\end{array}$ \\
\hline $\mathrm{CdL}$ & white & $136-138$ & 84 & 26.9 & 27.08 & {$\left[\mathrm{Cd}_{2} \mathrm{LCl}_{4}\right] \cdot \mathrm{H}_{2} \mathrm{O}$} \\
\hline
\end{tabular}

Table (2)

Characteristic stretching vibration frequencies $\left(\mathrm{cm}^{-1}\right)$ for the free ligand and its metal complexes.

\begin{tabular}{|c|c|c|c|c|c|c|c|c|}
\hline Comp. & $\boldsymbol{v}_{C=N+C=S}$ & $v_{C-S}$ & $v_{C=C}$ & $\delta_{=C H 2}$ & $v_{O H}$ & $v_{M-C}$ & $v_{M-S}$ & $v_{M-O}$ \\
\hline OBTM & 1265 & 731 & 1631 & $\begin{array}{l}949.6 \\
860.2\end{array}$ & - & - & - & - \\
\hline VL & 1252 & 722 & 1555 & $\begin{array}{l}920 \\
830 \\
\end{array}$ & 3510 & 415 & 444 & 515 \\
\hline $\mathrm{CrL}$ & 1250 & 720 & 1550 & $\begin{array}{l}920 \\
835\end{array}$ & 3504 & 418 & 450 & 525 \\
\hline NiL & 1250 & 720 & 1555 & $\begin{array}{l}922 \\
835\end{array}$ & 3514 & 418 & 420 & 520 \\
\hline $\mathrm{CdL}$ & 1255 & 724 & 1550 & $\begin{array}{l}922 \\
835 \\
\end{array}$ & 3430 & 418 & 472 & 532 \\
\hline
\end{tabular}


Table (3)

Electronic spectra, magnetic moment and conductance in DMF solvent for the prepared compounds.

\begin{tabular}{|c|c|c|c|c|c|}
\hline Comp. & $\begin{array}{c}\text { Bands } \\
\mathrm{cm}^{-1}\end{array}$ & Assignment & $\begin{array}{c}\text { Molar cond. } \\
\mu s \mathrm{~cm}^{-1}\end{array}$ & Meff B.M & $\begin{array}{l}\text { Suggested } \\
\text { structure }\end{array}$ \\
\hline VL & $\begin{array}{l}11570 \\
17422\end{array}$ & $\begin{array}{l}{ }^{2} \mathrm{~B}_{2} \rightarrow{ }^{2} \mathrm{E} \\
{ }^{2} \mathrm{~B}_{2} \rightarrow{ }^{2} \mathrm{~B}_{1}\end{array}$ & 15.8 & 2.1 & $\begin{array}{l}\text { Square } \\
\text { pyramid }\end{array}$ \\
\hline $\mathrm{CrL}$ & $\begin{array}{l}16590 \\
25936 \\
34758 \\
\end{array}$ & $\begin{array}{c}{ }^{4} \mathrm{~A}_{2} \mathrm{~g} \rightarrow{ }^{4} \mathrm{~T}_{2} \mathrm{~g} \\
{ }^{4} \mathrm{~A}_{2} \mathrm{~g} \rightarrow{ }^{4} \mathrm{~T}_{1} \mathrm{~g} \\
{ }^{4} \mathrm{~A}_{2} \mathrm{~g} \rightarrow{ }^{4} \mathrm{~T}_{1} \mathrm{~g}(\mathrm{p})\end{array}$ & 27.5 & 3.2 & Octahedral \\
\hline NiL & $\begin{array}{l}11725 \\
16980 \\
25390 \\
\end{array}$ & $\begin{array}{c}{ }^{3} \mathrm{~A}_{2} \mathrm{~g} \rightarrow{ }^{3} \mathrm{~T}_{2} \mathrm{~g} \\
{ }^{3} \mathrm{~A}_{2} \mathrm{~g} \rightarrow{ }^{3} \mathrm{~T}_{1} \mathrm{~g} \\
{ }^{3} \mathrm{~A}_{2} \mathrm{~g} \rightarrow{ }^{3} \mathrm{~T}_{1} \mathrm{~g}(\mathrm{p})\end{array}$ & 30.3 & 3.11 & Octahedral \\
\hline $\mathrm{CdL}$ & $\begin{array}{l}28375 \\
34753\end{array}$ & ILCT & 7.4 & 0.00 & Tetrahedral \\
\hline
\end{tabular}

ILCT: Internal Ligand Charge Transfer.

Table (4)

Antibacterial activities for the ligand and it"s metal complexes

\begin{tabular}{|c|c|c|c|c|}
\hline \multirow{2}{*}{ Comp. } & \multicolumn{2}{|c|}{ (-) pseudomonas aeruginosa } & \multicolumn{2}{|c|}{ (+) staphylococcus aureus } \\
\hline & $5 m M$ & $10 \mathrm{mM}$ & $5 m M$ & $10 m M$ \\
\hline $\mathrm{L}$ & - & - & + & + \\
\hline VL & +++ & ++ & +++ & ++ \\
\hline $\mathrm{CrL}$ & +++ & +++ & +++ & +++ \\
\hline NiL & - & - & + & + \\
\hline $\mathrm{CdL}$ & ++ & +++ & +++ & +++ \\
\hline
\end{tabular}

$(-)=$ no inhibition $=$ inactive

$(+)=(0.3-0.9) \mathrm{mm}=$ slightly active

$(++)=(0.9-1.2) \mathrm{mm}=$ moderately active

$(+++)=(1.2-1.6) \mathrm{mm}=$ active

Table (5)

Conformation energetic (in kcal) for the ligand and its metal complexes.

\begin{tabular}{|c|c|c|c|c|}
\hline \multirow{2}{*}{ Comp. } & \multirow{2}{*}{$\begin{array}{c}\text { HOMO } \\
(e v)\end{array}$} & \multirow{2}{*}{$\begin{array}{c}\text { LOMO } \\
(e v)\end{array}$} & \multicolumn{2}{|c|}{ PM3 } \\
\hline & & & $\Delta \boldsymbol{H}^{o} f$ & $\Delta E_{b}$ \\
\hline BTRZ & 8.959- & 0.581 & 164 & -4280 \\
\hline OВТМ & -8.725 & -0.592 & 198 & -5689 \\
\hline VL & - & - & - & - \\
\hline $\mathrm{CrL}$ & - & - & 258 & -6486 \\
\hline $\mathrm{NiL}$ & - & - & -145 & -7955 \\
\hline $\mathrm{CdL}$ & - & - & 561 & -5891 \\
\hline
\end{tabular}

Table (6) 
Comparison of experimental and theoretical vibration frequencies.

\begin{tabular}{|c|c|c|c|c|c|}
\hline Comp. & $v_{S H}$ & $v_{C=N}$ & $v_{C-S}$ & $v_{C=C}$ & $\delta_{=C H 2}$ \\
\hline BTRZ & $\begin{array}{c}2550 * \\
2591 * * \\
(1.607) * * * \\
\end{array}$ & $\begin{array}{c}1580 * \\
1563 * * \\
(5.886) * * *\end{array}$ & $\begin{array}{c}765 * \\
827 * * \\
(8.235) * * *\end{array}$ & - & - \\
\hline OBТM & - & - & $\begin{array}{c}731 * \\
804 * * \\
(9.986) * * *\end{array}$ & $\begin{array}{c}1631.7 * \\
1639.20 * * \\
(0.490) * * *\end{array}$ & $\begin{array}{c}949.6 * \\
967.65 * * \\
(1.896) * * *\end{array}$ \\
\hline
\end{tabular}

\section{Where:}

*experimental data.

** Theoretical data.

*** Differences between the experimental and theoretical data.

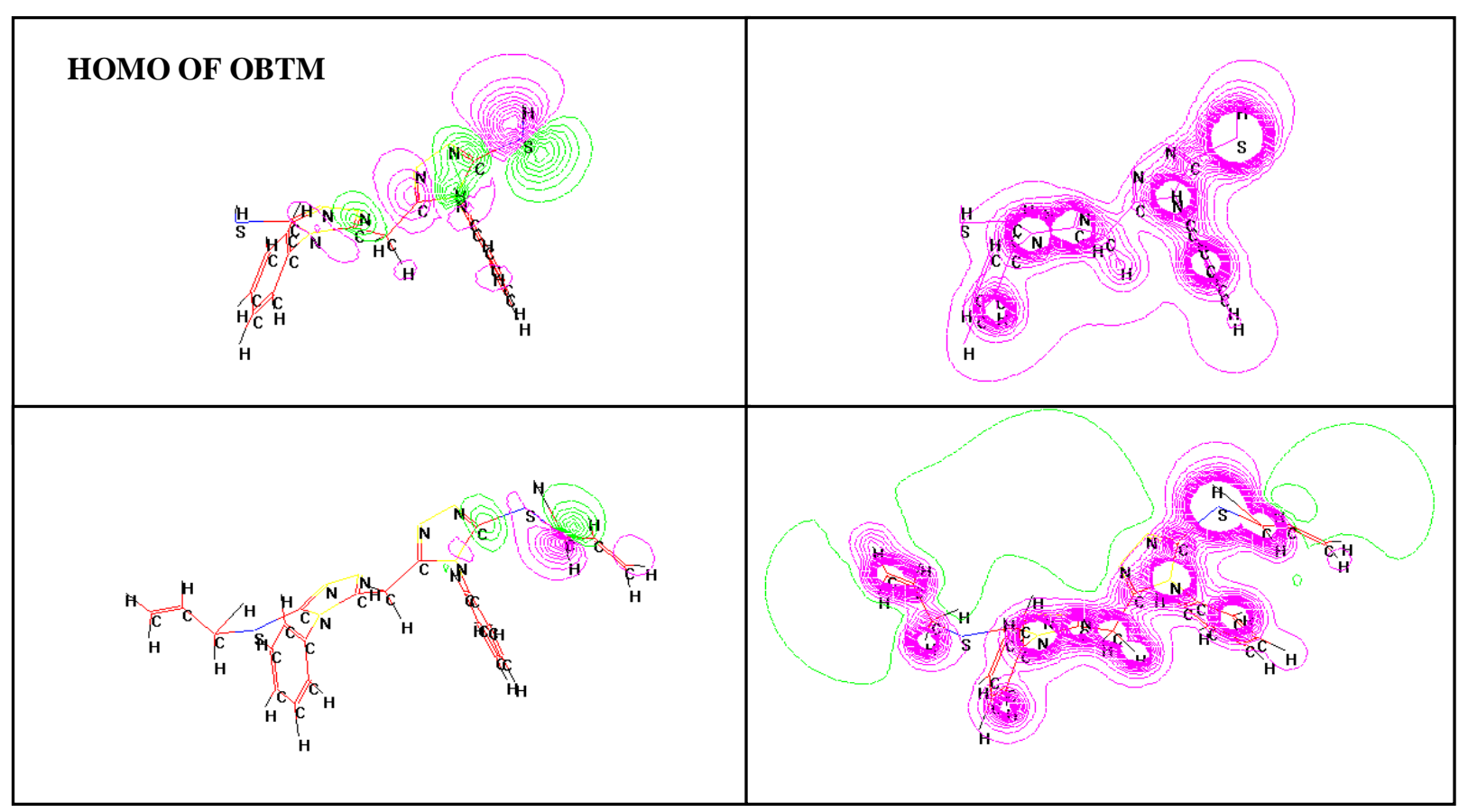

Fig. (1) HOMO and Electrostatic Potential as 2D Contours for BTRZ and OBTM. 


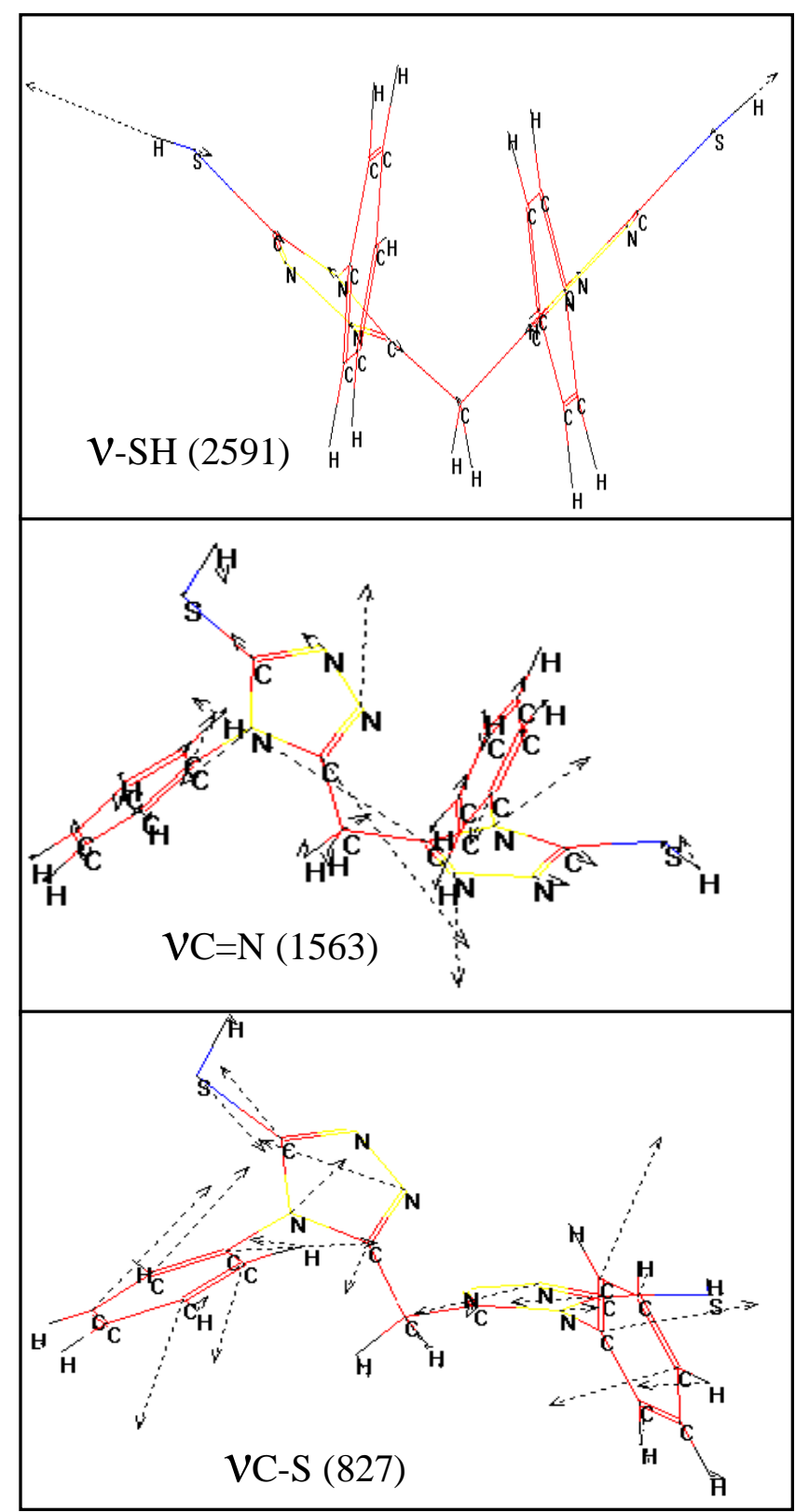

Fig. (2) The Calculated Vibration

Frequencies of (BTRZ).

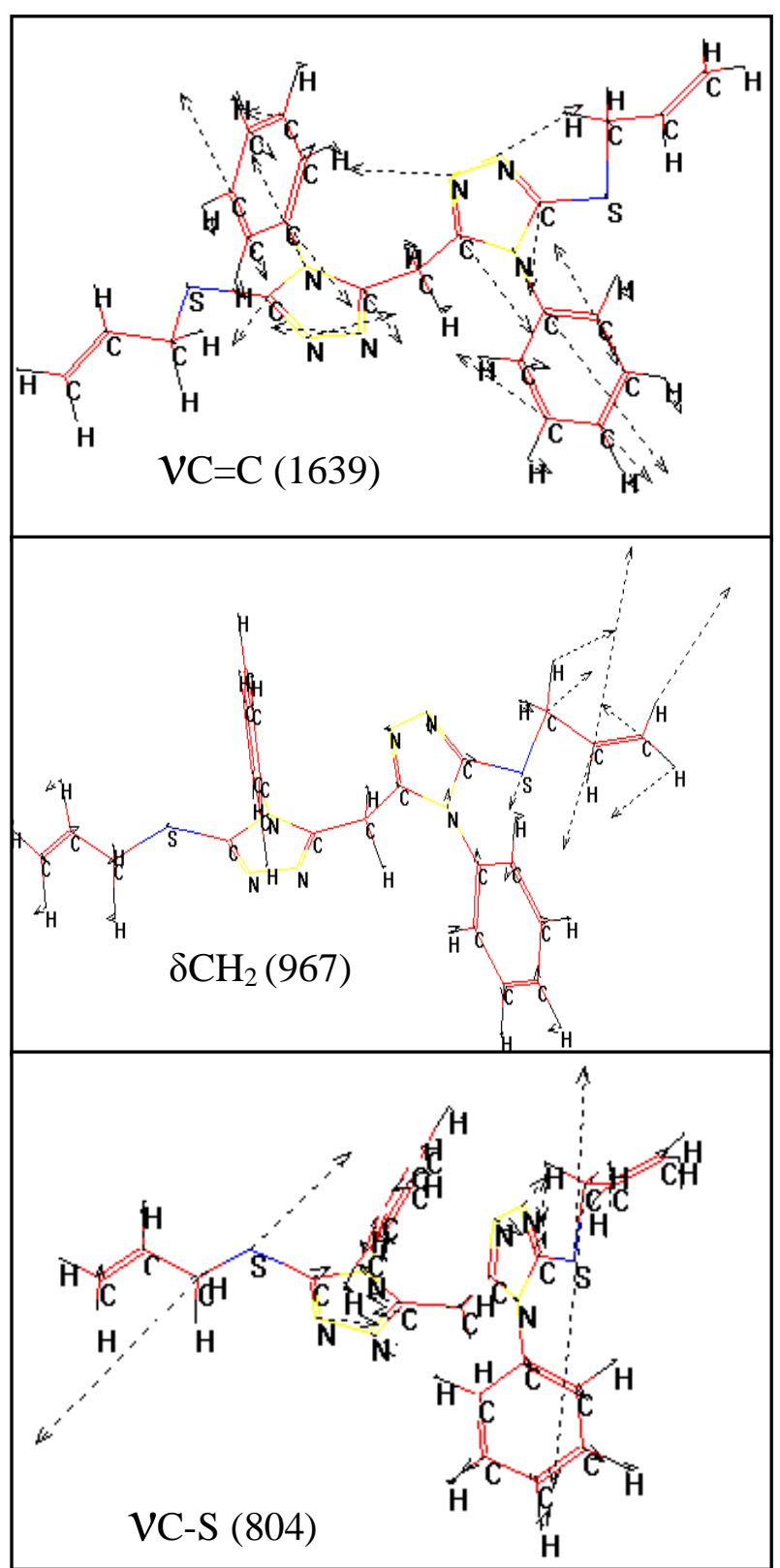

Fig. (3) The Calculated Vibration Frequencies of (OBTM). 


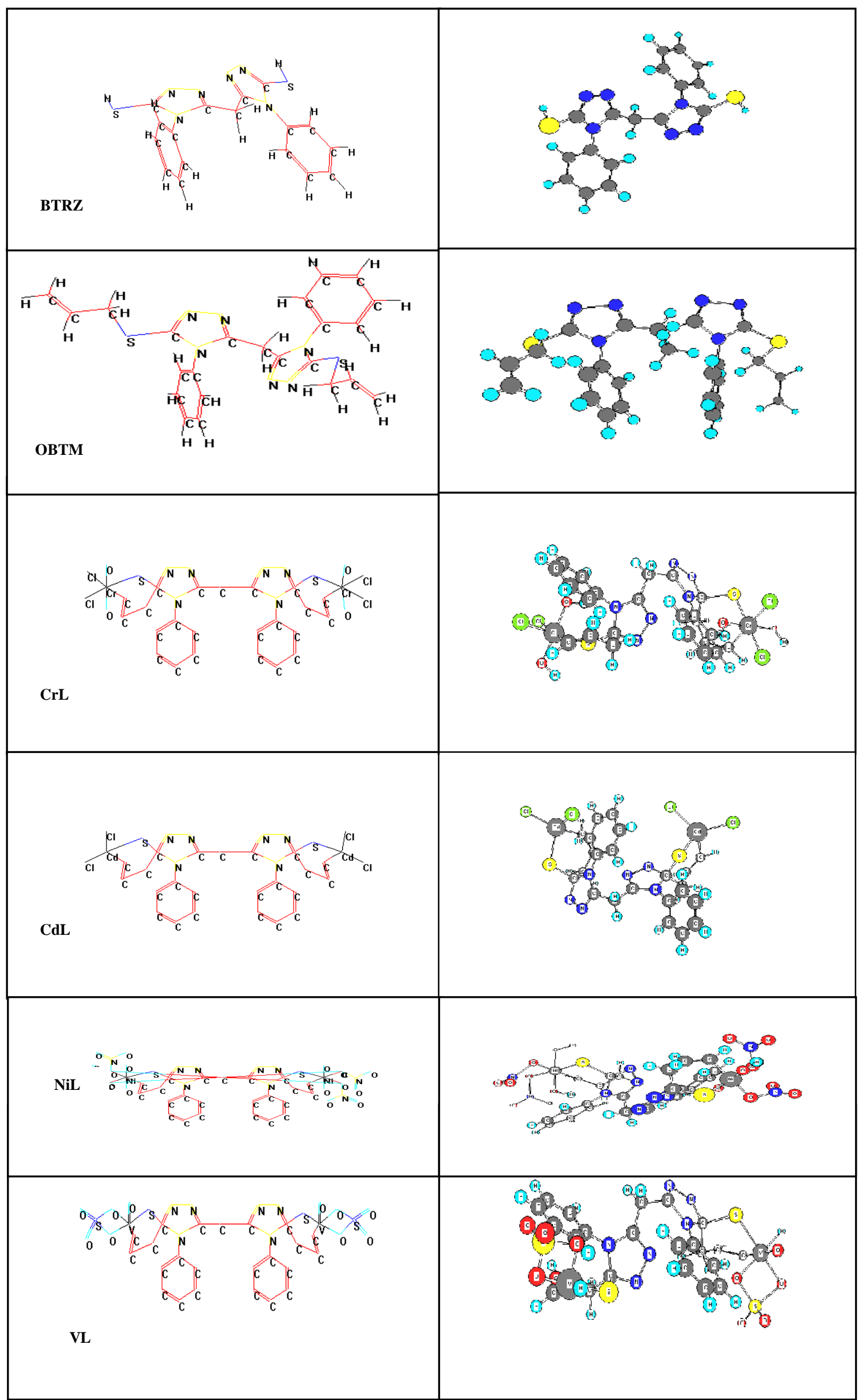

Fig. (4) Conformational Structure of BTRZ and OBTM and its Complexes. 


\section{Conclusion}

The ligand behave as a tetradentate chelating with two sulfur atoms and two olefinic groups, to form an octahedral geometry for the chromium and nickel complexes and a tetrahedral geometry for the cadmium complex, in addition to square pyramid for the vanadium complex. The theoretical calculation data of the frequencies for the ligand and its complexes agreed and help to assign un ambiguously the most diagnostic bands.

\section{References}

[1] R. Chang, " Chemistry " $6^{\text {th }}$ Ed. New York, Sanfrancisco (1998).

[2] R.C. Mirash, B.K. Mohaptra, and D. Panda, J.Indian Chem., Soc. 20, 80 (1983).

[3] B.L. Kalluraya and P.Q. Gunaga, Ind. J. Chem. 38 (11), 1295, (1999).

[4] a) Methuen, " Organometallic Compounds "Coats Green and Wade, Vol (II), Green, M. I. H. (1988).

b) L. G. Miessler and A. T. Donald, "Inorganic Chemistry ", $2^{\text {nd }}$ ed., PrenticeHall, Inc. (1999).

[5] J. Oliver, Organometallic, 1, 1307 (1982).

[6] M.F. Alias and A.H. Jassim, J. of College of Education for Women, 14 (1), 177 (2003).

[7] M.F. Alias, A.J. Hashim and T.A. Kareem, Ibn Al-Haitham J. for Pure and Applied Sciences vol. (21), (2) (2008).

[8] HyperChem 6.0 user manuals, Hypercube, Inc, FL1996 VRL-Http://www.Hyper.com/.

[9] J. Foresman, and C. Frish, " Exploring Chemistry with Electronic Structure Methods", $2^{\text {nd }}$ ed., Gaussian Inc., Pittsburgh, PA., (1996).

[10] L.J.V. Piddock, J. Applied Bacteriology, 68, 307 (1990).

[11] K. Nakamoto, " Infrared of Inorganic and Coordination Compounds " $6^{\text {th }}$ ed., John Wiely, Inc., New York (1997).

[12] N.N. Greenwood and A. Earnshaw, "Chemistry of Elements", $2^{\text {nd }}$ Ed. Prigman Press (1998).

[13] B. Singh and K.P. Thakup, J. Inorg. Nucl. Chem., 36, 1735 (1974).

[14] D. Nicholas, " Complexes and First-row Transition Element, "Translated by W. I. Azeez (1984).
[15] U.N. Kumari and C.P. Single, J. Ind. Chem., Soc. LVII (8) (1990).

[16] a) C. K. Jorgensen " Modern Aspect of Ligand Field Theory " Elsevier; New York, (1971).

b) A. B. P. Lever "Inorganic Electronic Spectroscopy ", $2^{\text {nd }}$ ed.; Elsevier; New York, (1986).

[17] K. Burger, " Coordination Chemistry Experimental Methods ", London, Co. Publishers Ltd. (1973).

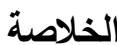

جرى تحضير الليكاند ثثائي (4-فنيل-3(2-3بروبينيل) ثايو -4,2,1-ترايازول-5 يل) ميثان ومعقداته مـع ايونات كل

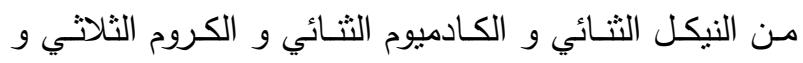

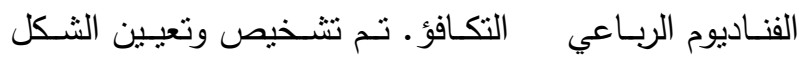

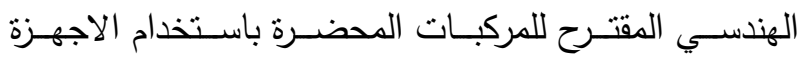

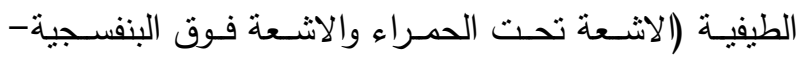
المرئيــة) بالاضــافة الـــ قيــاس الحساسـية المغناطيسـية والتوصيل الكهربائي لها.

جرى معالجة تكوين المعقدات نظريا في الطور الغازي باستخدام الطرق شبه التجريبية لحساب حرارة التكوين وطاقة الترابط عند درجة حرارة 298 كلفن لليكاند ومعقداته المحضرة, كذلك تم حساب الجه الاككتروستانيكي لبيان المواقع الفعالة لليكاند وجرى حساب التردد الاهتزازي نظريا ومقارنته مع القيم المقاسة عمليا اذ وجد ان هناك تقاربا بين القيم المقاسة عمليا وتلك المحسوبة نظريا مع زيادة امكانية تشخيص الحزم بشكل ادق. تم تقويم الفعالية المضادة

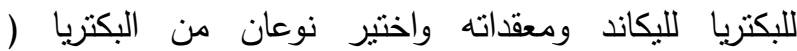
.( staphylococcus aureus g pseudomonas aeruginosa 